\title{
Quality evaluation of soil-cement-plant residue bricks by the combination of destructive and non-destructive tests
}

\author{
Regis de C. Ferreira ${ }^{1} \&$ Ananda H. N. Cunha ${ }^{1}$ \\ ${ }^{1}$ Universidade Federal de Goiás/Escola de Agronomia. Goiânia, GO. E-mail: regisdecastroferreira@gmail.com (Corresponding author); analena23@gmail.com
}

\section{Key words:}

soil stabilization

rice husk

anisotropic resistance

\begin{abstract}
A B S T R A C T
Residues from agricultural activity can be used to improve the quality of soil-based bricks, constituting an interesting alternative for their destination. The technical quality of soilcement-plant residue bricks was evaluated by the combination of non-destructive and destructive methods. A predominant clayey soil, Portland cement and residues of husks of both rice and Brachiaria brizantha cv. Marandu (0, 10, 20, 30 and 40\%, in mass, in substitution to the $10 \%$ cement content) were used. The bricks were submitted to destructive (water absorption and compressive strength) and nondestructive (ultrasound) tests for their physical and mechanical characterization. Results from both destructive and non-destructive tests were combined to determine the quantitative parameter named "anisotropic resistance" in order to evaluate the quality of the bricks. The addition that promoted best technical quality was $10 \%$ residue content, regardless of the residue type. The anisotropic resistance proved to be adequate for the technical quality evaluation of the bricks.
\end{abstract}

\section{Palavras-chave:}

estabilização de solos

casca de arroz

resistência anisotrópica

\section{Avaliação da qualidade de tijolos de solo-cimento-resíduos vegetais por meio da combinação de testes destrutivos e não-destrutivos}

\section{R E S U M O}

Resíduos provenientes da atividade agrícola podem ser utilizados para a melhoria da qualidade de tijolos, constituindo-se como interessante alternativa de sua destinação. Avaliou-se a qualidade técnica de tijolos de solo-cimento-resíduos vegetais pela combinação de testes destrutivos e não-destrutivos. Utilizou-se um solo predominantemente argiloso, cimento CP II-F 32 e resíduos das cascas de arroz e de braquiária (Brachiaria brizantha cv. Marandu) nos teores (em massa) de 0, 10, 20, 30 e 40\% em substituição ao teor de $10 \%$ do cimento. Os tijolos foram submetidos a ensaios destrutivos (absorção de água e compressão simples) e não-destrutivos (ultrassom) para sua caracterização físico-mecânica; em seguida, os resultados dos ensaios destrutivos e não-destrutivos foram combinados para se determinar o parâmetro "resistência anisotrópica" utilizado na avaliação da qualidade técnica dos tijolos, tendo sido obtido o melhor resultado com o teor de $10 \%$ de resíduo em substituição ao cimento, independentemente do tipo do resíduo. Concluiu-se que a resistência anisotrópica se mostra adequada para a avaliação da qualidade técnica dos tijolos. 


\section{INTRODUCTION}

The agricultural activity generates residues that can be used to manufacture unconventional construction materials. Because of the problem of searching adequate disposal, recent studies have reported the use of agro-industrial residues in the manufacture of pressed bricks (Faria et al., 2012; Madurwar et al., 2013; Zhang, 2013; Ganga et al., 2014; Laborel-Préneron et al., 2016).

Rice husk has been object of studies to improve the physical-mechanical characteristics of mortar and/or construction materials based on raw earth (Ferreira et al., 2008). The major advantage of using rice husk as alternative aggregate lies in the fact that its generation is concentrated in few places, which facilitates its marketing. In addition, the granulometry of the material is relatively uniform, which facilitates the dosage of the composite. A similar situation occurs with the residues originated from processing plants of seeds of forage species, such as Brachiaria grass (Brachiaria brizantha). The husk that involves the seed is, most of the times, discarded, due to the inexistence of more adequate use. On the other hand, Ferreira et al. (2008) report the need of previous procedures aiming at the utilization of these residues in the manufacture of raw earth-based materials. Such treatments include grinding the husks in hammer mill grinder, sieving to eliminate fine material, standardization and improvement of biomass adhesion to the soil-cement system and immersion in $5 \%$ concentrated lime solution, for a period of $24 \mathrm{~h}$. This pre-treatment favors the minimization of the incompatibility between the vegetal biomass and Portland cement, besides allowing to remove extractives that solubilize in the water and inhibit cement hydration.

In general, the quality of soil-cement mixtures is evaluated through destructive tests, such as those of simple compression and water absorption. Likewise, quality can be evaluated through non-destructive tests, such as the ultrasonic wave propagation technique (Cazalla et al., 1999; Qasrawi, 2000; Cultrone et al., 2001; Ferreira \& Freire, 2004; Brozovsky, 2014; Carrasco et al., 2014; Ganga et al., 2014).

Cultrone et al. (2001), studying the influence of different raw materials on the quality of fire bricks, proposed the concept of "anisotropic resistance" as a quantitative parameter to evaluate brick quality, combining the results of simple compression (destructive method) and structural anisotropy (non-destructive method).

The use of anisotropic resistance to measure the quality of a brick is based on the relationship between the physical stress produced on the brick during the compression test and a mathematical parameter (its anisotropic structure). The higher its value, the better the quality of the material (Carrasco et al., 2014).

Thus, the present study investigated the effect of the addition of plant residues on the mechanical and elastic-acoustic properties of soil-cement bricks and evaluated the combination of quantitative and qualitative criteria, respectively, through the utilization of the results of compressive strength and water absorption capacity, and total anisotropy and anisotropic resistance for the analysis of the quality of these bricks.

\section{Material and Methods}

The experiment was carried out at the Laboratories of Soil Mechanics and Construction Materials, of the Civil Engineering School, and at the Laboratory of Biosystems Engineering, of the Agronomy School, both of the Federal University of Goiás ( $16^{\circ} 35^{\prime} 47^{\prime \prime}$ S; 49 $16^{\prime} 47^{\prime \prime}$ W, 730 m).

The experiment used the soil and plant residues previously characterized by Ferreira \& Oliveira (2007). The soil had clayey texture, predominant of the municipality of Goiânia, Goiás. The samples were collected at depth of $1.0 \mathrm{~m}$ to avoid the surface layer, due to the excessive presence of organic matter and alteration in the quantity of fine material through leaching.

Firstly, the collected soil proved to be inadequate for utilization in soil-cement mixtures, with limits of consistency and clay content in disagreement with the ABNT (1989). Thus, its granulometry was corrected through the addition of sand, to make it meet the norm (100\% passing through $4.78 \mathrm{~mm}$ mesh sieve, 10 to $50 \%$ passing through $0.075-\mathrm{mm}$-mesh sieve, liquid limit $\leq 45 \%$ and plasticity index $\leq 18 \%)$. The mixture received Portland cement CP II-E-32 (ABNT, 1991), which is composed by blast furnace slag, combining good results of low hydration heat with increase of resistance. This type of cement is commonly used in soil-cement mixtures to promote relatively slow heat release and be tolerant to the attack of sulfates from the soil (Cruz \& Jalali, 2010).

The plant residues (rice and Brachiaria seed husks) were obtained in rice and forage seed processing plants of the municipality of Goiânia, Goiás. In its natural condition, rice husk was characterized as a light material, with bulk density of $0.086 \mathrm{~g} \mathrm{~cm}^{-3}$ and uniform granulometry ( $89 \%$ between the sieves of 2.00 and $1.19 \mathrm{~mm}$ mesh). On the other hand, after undergoing the processes of fractionation, sieving and pretreatment, rice husk bulk density increased to $0.152 \mathrm{~g} \mathrm{~cm}^{-3}$. The pre-treatment consisted in the immersion of rice husks in $5 \%$ hydrated lime solution $(24 \mathrm{~h})$ and subsequent drying in an oven at $80^{\circ} \mathrm{C}(48 \mathrm{~h})$ (Ramakrishna \& Sundararajan, 2005) to minimize the chemical incompatibility between the cement and the husks. Approximately $90 \%$ of its mass showed diameter ranging from 1.19 to $0.42 \mathrm{~mm}$. Brachiaria seed husks, in their natural condition, were characterized as a light material, with bulk density of $0.059 \mathrm{~g} \mathrm{~cm}^{-3}$ and uniform granulometry (91\% between the sieves of 2.00 and $1.19 \mathrm{~mm}$ mesh). After undergoing the processes of fractionation, sieving and pre-treatment with hydrated lime solution, the bulk density increased to $0.096 \mathrm{~g} \mathrm{~cm}^{-3}$, and $83 \%$ of its mass showed diameter ranging from 2.00 to $0.105 \mathrm{~mm}$.

In order to add maximum amount of residues and reduce the cement consumption in the soil-cement-residue mixture, the content of $10 \%$ of the cement-residue combination was adopted, considered in relation to the dry soil weight in the fraction smaller than $4.78 \mathrm{~mm}$ and in its natural moisture content, according to the procedures adopted by Milani \& Freire (2006).

The contents of cement and residue varied from $100 \%$ cement $+0 \%$ residue to $60 \%$ cement $+40 \%$ residue (in relation to the content of $10 \%$ cement), totaling nine mixtures (treatments), as follows: $\mathrm{T}_{1}-$ soil $+0 \%$ of additions $(0 \%$ 
residue $+100 \%$ cement $)$ - control; $\mathrm{T}_{2}-$ soil $+10 \%$ of additions ( $10 \%$ rice husk $+90 \%$ cement $) ; \mathrm{T}_{3}-$ soil $+10 \%$ of additions ( $20 \%$ rice husk $+80 \%$ cement $) ; \mathrm{T}_{4}-$ soil $+10 \%$ of additions ( $30 \%$ rice husk $+70 \%$ cement $) ; \mathrm{T}_{5}-$ soil $+10 \%$ of additions ( $40 \%$ rice husk $+60 \%$ cement $) ; \mathrm{T}_{6}-$ soil $+10 \%$ of additions ( $10 \%$ Brachiaria seed husk $+90 \%$ cement $) ; \mathrm{T}_{7}-$ soil $+10 \%$ of additions (20\% Brachiaria seed husk $+80 \%$ cement); $\mathrm{T}_{8}-$ soil $+10 \%$ of additions ( $30 \%$ Brachiaria seed husk $+70 \%$ cement) and; $\mathrm{T}_{9}-$ soil $+10 \%$ of additions $(40 \%$ Brachiaria seed husk $+60 \%$ cement).

The bricks were molded according to ABNT (1989) in a manually operated brick making machine (Brand: Tecmor) with capacity for three bricks $\left(23 \times 11 \times 5 \mathrm{~cm}^{3}\right)$ per pressing (ABNT, 1992a). To reach maximum apparent specific weight of the bricks, for the molding, the present study adopted the values of optimum moisture obtained in the Normal Proctor compaction tests, previously conducted by Ferreira et al. (2008) (Table 1). After molding, the bricks were cured in humid chamber at $23 \pm 2{ }^{\circ} \mathrm{C}$ and relative humidity of $90 \pm 2 \%$, for 7 days, and then stored in the open air and protected from inclement weather until the age of 182 days.

At 7, 28, 56, 91 and 182 days, test specimens (prismatic) were prepared by sawing the bricks in half (transversely to their length), joining both halves and coating of the working sides with Portland cement paste of plastic consistency, with the minimum thickness necessary to obtain flat and parallel faces. Then, the test specimens were ruptured under simple compression in a universal test machine (Dynatest) with capacity for $2.500 \mathrm{kN}$, adopting the loading speed of $1 \mathrm{~mm}$ $\mathrm{min}^{-1}$. Resistance was calculated by dividing the rupture load by the transverse section area of the brick and the mean resistance obtained in three replicates. The water absorption test was performed at the age of seven days. Both tests were conducted according to ABNT (1992b).

The ultrasonic wave propagation velocity was obtained using an ultrasound device (Steinkamp/BP7, Germany) with emission of ultrasonic pulse at frequency of $45 \mathrm{kHz}$ and equipped with two flat-section transducers (Figure 1A), one emitter and the other receiver of the pulse. Previous studies (Cazalla et al., 1999; Ferreira \& Freire, 2004; Carrasco et al., 2014) have demonstrated that it is possible to relate the wave velocity in the three directions and, thus, characterize the structural anisotropy (total anisotropy) of the bricks (Eq. 1).

$$
\Delta \mathrm{M}=100\left[1-\frac{2 \mathrm{~V}_{1}}{\left(\mathrm{~V}_{2}+\mathrm{V}_{3}\right)}\right]
$$

where:

$\Delta \mathrm{M}$ - total anisotropy (\%); and,

$\mathrm{V}_{1}, \mathrm{~V}_{2}$ and $\mathrm{V}_{3}$ - ultrasonic wave velocity $\left(\mathrm{m} \mathrm{s}^{-1}\right)$, respectively measured in the shortest distance (thickness), transverse distance and longitudinal distance (Figure 1B).

The parameter "anisotropic resistance" - $\mathrm{R}_{\mathrm{A}}$, $\left(\mathrm{MPa} \%{ }^{-1}\right)$ Cultrone et al. (2001) was used to measure the technical quality of bricks in physical-mechanical and elastic-acoustic terms (Eq. 2 ). Higher $R_{A}$ values indicate low anisotropy of the crystalline structure of the bricks, associated with the low presence of

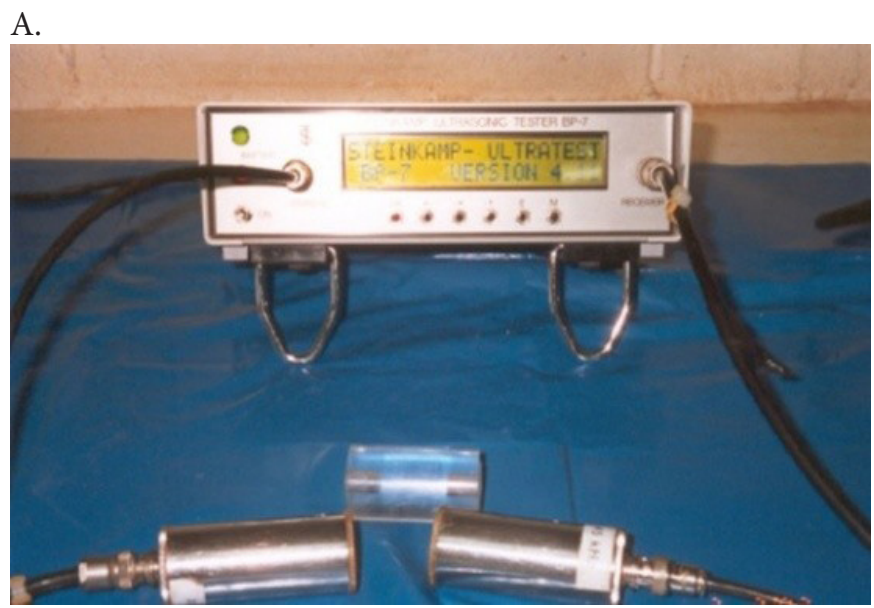

B.

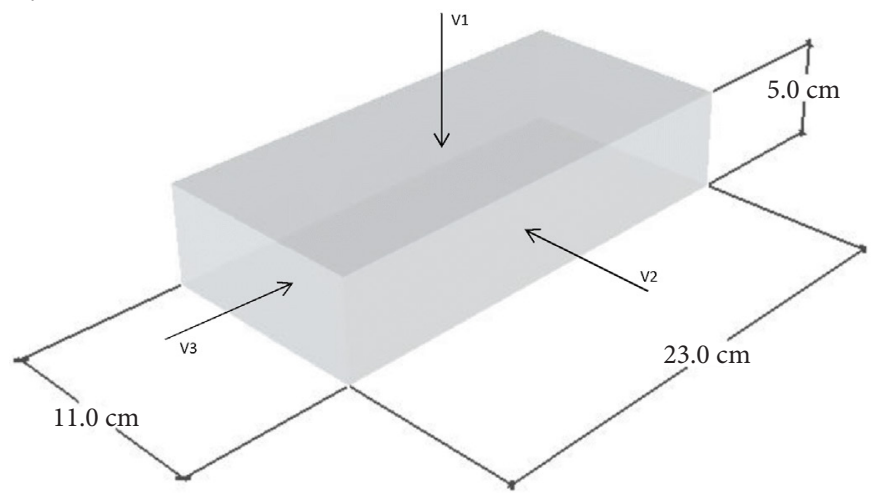

Figure 1. Non-destructive evaluation of the bricks: portable ultrasound device (A), Reading directions of ultrasonic pulse propagation velocity, dimensions in $\mathrm{cm}(\mathrm{B})$

empty spaces, with higher values of mechanical resistance $\left(R_{c}\right)$ and durability and, consequently, better quality.

$$
\mathrm{R}_{\mathrm{A}}=\frac{\mathrm{R}_{\mathrm{C}}}{\Delta \mathrm{M}}
$$

Tests were also conducted to determine the dynamic modulus of elasticity (Ed), according to the recommendations of Naik et al. (2014), who relate ultrasonic wave velocity through solid materials to the physical properties of these solids (Eq. 3).

$$
E d=\rho V^{2} \frac{(1+\mu)(1-2 \mu)}{(1-\mu)}
$$

where:

$\rho \quad$ - apparent specific weight of the brick, $\mathrm{kg} \mathrm{m}^{-3}$;

$\mathrm{V}$ - ultrasonic pulse velocity, $\mathrm{m} \mathrm{s}^{-1}$; and,

$\mu \quad$ - Poisson coefficient.

Since it is impossible to obtain the Poisson coefficient experimentally, the value of 0.19 was used (Mosalam et al., 2009).

The experiment was conducted in completely randomized design, in a 2 x 5 factorial scheme. ANOVA was used to study the effects of the interactions between the types of residue (rice and Brachiaria seed husks), contents of residue $(0,10$, 20,30 and 40\%) and ages $(7,28,56,91$ and 182 days) on the 
response variables $R_{C}$ and $R_{A}$. The results were compared by Tukey test at 0.01 probability level $(\mathrm{p}<0.01)$ using the mean of three replicates.

\section{Results AND Discussion}

The presence of residues caused greater energy dissipation during the molding of the bricks, leading to reduction in the maximum dry apparent specific weight and increase in optimal moisture of compaction, following the same behavior observed in the Normal Proctor compaction tests previously performed by Ferreira et al. (2008) (Table 1).

ABNT (1992a) establishes that the cement content to be employed in the manufacture of bricks is the one that gives minimum resistance of $2.0 \mathrm{MPa}$ and maximum water absorption of $20 \%$, at 7 days. For non-normed bricks, as in the present study, the norm suggests minimum of $1.5 \mathrm{MPa}$ for sealing purposes. As the residue content increased the resistance, the simple compression significantly decreased (Table 2).

Khedari et al. (2005) claimed that the presence of aggregates and vegetal fibers can cause reduction in the resistance of bricks due to the weak adhesion between the particles and the matrix. The best mechanical performances were achieved by the treatments $T_{2}$ and $T_{6}$. The addition of rice husk resulted in higher values of resistance to compression compared with Brachiaria seed husk, at the equivalent contents and at all ages. The more residues incorporated to the matrix, the greater the difference of resistance in favor of rice husk, compared with the addition of Brachiaria seed husk. Jauberthie et al. (2003) reported that this advantage can be attributed to the modification in the organic part of the rice husk, due to the high alkalinity of the water in the pores in the region of the rice husk, whose silica content is higher than that of Brachiaria seed husk. Such modification in the chemical composition of the husk allows greater interaction of the cement with the silica present in the rice husk, which probably eliminates starch remnants still adhered to the husk, favoring the formation of calcium silicate hydrate (C-S-H). The C-S-H's have porous structure and large specific surface (Yu et al., 1999), which contributes to the increase of the bonds between oxides present in the soils (iron sesquioxides, $\mathrm{Fe}_{2} \mathrm{O}_{3}$ ), aluminates (alumina, $\mathrm{Al}_{2} \mathrm{O}_{3}$ ) and iron-aluminates (tetracalcium iron-aluminates, $\mathrm{C}_{4} \mathrm{AF}$ ). Like the C-S-H's, these oxides are products of the Portland cement hydration, which positively influence also the physical and mechanical properties of matrices based on soil-cement.

The increment in the residue content increased the water absorption due to the lower apparent specific weight; higher values occurred in the treatments with greater addition of residue.

Table 1. Maximum dry apparent specific weight and optimal moisture of compaction of the soil-cement-residue mixtures in Normal Proctor compaction tests

\begin{tabular}{|c|c|c|c|c|c|c|c|c|c|c|c|c|c|c|c|c|c|}
\hline \multicolumn{9}{|c|}{ Specific weight $\left(\mathrm{g} \mathrm{cm}^{-3}\right)$} & \multicolumn{9}{|c|}{ Optimal moisture of compaction (\%) } \\
\hline $\mathrm{T}_{1}$ & $\mathrm{~T}_{2}$ & $\mathrm{~T}_{3}$ & $\mathrm{~T}_{4}$ & $\mathrm{~T}_{5}$ & $\mathrm{~T}_{6}$ & $\mathrm{~T}_{7}$ & $\mathrm{~T}_{8}$ & $T_{9}$ & $\mathrm{~T}_{1}$ & $\mathrm{~T}_{2}$ & $\mathrm{~T}_{3}$ & $\mathrm{~T}_{4}$ & $\mathrm{~T}_{5}$ & $\mathrm{~T}_{6}$ & $\mathrm{~T}_{7}$ & $\mathrm{~T}_{8}$ & $T_{9}$ \\
\hline 1.8 & 1.7 & 1.7 & 1.7 & 1.7 & 1.8 & 1.7 & 1.7 & 1.7 & 16.7 & 17.7 & 18.6 & 18.2 & 19.3 & 16.9 & 18.5 & 19.0 & 19.9 \\
\hline
\end{tabular}

Source: Ferreira et al. (2008)

$T_{1}-$ Soil $+0 \%$ of additions ( $0 \%$ residue $+100 \%$ cement) - control; $T_{2}-$ Soil $+10 \%$ of additions $\left(10 \%\right.$ rice husk $+90 \%$ cement) $; T_{3}-$ Soil $+10 \%$ of additions $(20 \%$ rice husk $+80 \%$ cement); $T_{-}-$Soil $+10 \%$ of additions ( $30 \%$ rice husk $+70 \%$ cement) $; T_{5}-$ Soil $+10 \%$ of additions $\left(40 \%\right.$ rice husk $+60 \%$ cement); $T_{-}-$Soil $+10 \%$ of additions ( $10 \%$ Brachiaria seed husk $+90 \%$ cement); $\mathrm{T}_{7}-$ Soil $+10 \%$ of additions ( $20 \%$ Brachiaria seed husk $+80 \%$ cement); $\mathrm{T}_{8}-$ Soil $+10 \%$ of additions ( $30 \%$ Brachiaria seed husk $+70 \%$ cement) and; $\mathrm{T}_{9}-$ Soil + $10 \%$ of additions ( $40 \%$ Brachiaria seed husk $+60 \%$ cement)

Table 2. Resistance to simple compression and total water absorption capacity of soil-cement- plant residues bricks

\begin{tabular}{|c|c|c|c|c|c|c|}
\hline \multirow{2}{*}{ Treat. } & \multicolumn{5}{|c|}{ Resistance to simple compression (MPa) - days } & \multirow{2}{*}{$\begin{array}{c}\text { Total water absorption } \\
\text { (\%) } \\
7 \text { days }\end{array}$} \\
\hline & 7 & 28 & 56 & 91 & 182 & \\
\hline $\mathrm{T}_{1}$ & $\begin{array}{r}3.00 \pm 0.27 \\
(9.08) \mathrm{a} \mathrm{C}^{1}\end{array}$ & $\begin{array}{c}3.07 \pm 0.05 \\
(1.68) \text { a C }\end{array}$ & $\begin{array}{l}4.80 \pm 0.52 \\
(10.88) \text { a } A\end{array}$ & $\begin{array}{c}3.83 \pm 0.09 \\
(2.23) \text { a B }\end{array}$ & $\begin{array}{c}4.96 \pm 0.35 \\
(7.10) \mathrm{a} \mathrm{A}\end{array}$ & $\begin{array}{c}11.42 \pm 3.41 \\
(29.90)\end{array}$ \\
\hline $\mathrm{T}_{2}$ & $\begin{array}{c}1.82 \pm 0.09 \\
(4.91) \text { b C }\end{array}$ & $\begin{array}{c}2.25 \pm 0.05 \\
(2.30) \text { b B }\end{array}$ & $\begin{array}{c}2.89 \pm 0.16 \\
(5.59) \text { b A }\end{array}$ & $\begin{array}{c}2.52 \pm 0.05 \\
(1.96) \text { b B }\end{array}$ & $\begin{array}{c}2.74 \pm 0.10 \\
(3.55) \text { b A }\end{array}$ & $\begin{array}{c}12.97 \pm 3.06 \\
(23.59)\end{array}$ \\
\hline $\mathrm{T}_{3}$ & $\begin{array}{c}1.34 \pm 0.05 \\
(3.86) \text { C C }\end{array}$ & $\begin{array}{l}1.52 \pm 0.04 \\
(2.57) \mathrm{c} \mathrm{BC}\end{array}$ & $\begin{array}{c}2.21 \pm 0.06 \\
(2.92) \text { C A }\end{array}$ & $\begin{array}{c}1.77 \pm 0.07 \\
(3.81) \text { C B }\end{array}$ & $\begin{array}{c}2.40 \pm 0.13 \\
(5.63) \subset A\end{array}$ & $\begin{array}{c}13.78 \pm 3.75 \\
(27.20)\end{array}$ \\
\hline $\mathrm{T}_{4}$ & $\begin{array}{l}1.07 \pm 0.07 \\
(6.28) \mathrm{cd} \mathrm{C}\end{array}$ & $\begin{array}{l}1.21 \pm 0.04 \\
(3.21) \mathrm{cd} \mathrm{BC}\end{array}$ & $\begin{array}{l}1.40 \pm 0.18 \\
(12.73) \mathrm{d} B\end{array}$ & $\begin{array}{c}1.54 \pm 0.03 \\
(2.09) \mathrm{CA}\end{array}$ & $\begin{array}{c}1.75 \pm 0.05 \\
(2.95) \mathrm{d} \mathrm{A}\end{array}$ & $\begin{array}{c}16.42 \pm 5.79 \\
(35.27)\end{array}$ \\
\hline $\mathrm{T}_{5}$ & $\begin{array}{c}0.98 \pm 0.02 \\
(1.99) \mathrm{d} \mathrm{B}\end{array}$ & $\begin{array}{c}1.03 \pm 0.00 \\
(0.00) \mathrm{d} \mathrm{B}\end{array}$ & $\begin{array}{l}1.00 \pm 0.13 \\
(13.42) \text { e } B\end{array}$ & $\begin{array}{l}1.15 \pm 0.03 \\
(2.82) \text { de B }\end{array}$ & $\begin{array}{c}1.63 \pm 0.04 \\
(2.40) \mathrm{d} \mathrm{A}\end{array}$ & $\begin{array}{c}18.51 \pm 4.97 \\
(26.88)\end{array}$ \\
\hline $\mathrm{T}_{6}$ & $\begin{array}{l}1.53 \pm 0.15 \\
(10.11) b D\end{array}$ & $\begin{array}{c}2.16 \pm 0.07 \\
(3.25) \text { b C }\end{array}$ & $\begin{array}{l}2.61 \pm 0.28 \\
(10.78) b B\end{array}$ & $\begin{array}{l}2.35 \pm 0.11 \\
(4.83) \mathrm{b} \mathrm{BC}\end{array}$ & $\begin{array}{c}2.99 \pm 0.12 \\
(3.96) \text { b A }\end{array}$ & $\begin{array}{c}12.33 \pm 2.80 \\
(22.75)\end{array}$ \\
\hline $\mathrm{T}_{7}$ & $\begin{array}{l}1.07 \pm 0.07 \\
(6.28) \mathrm{cd} \mathrm{B}\end{array}$ & $\begin{array}{c}1.17 \pm 0.05 \\
(4.40) \mathrm{d} \mathrm{B}\end{array}$ & $\begin{array}{c}1.58 \pm 0.06 \\
(4.08) \mathrm{d} \mathrm{A}\end{array}$ & $\begin{array}{c}1.33 \pm 0.05 \\
(3.70) \mathrm{d} \mathrm{B}\end{array}$ & $\begin{array}{c}1.75 \pm 0.07 \\
(4.01) \mathrm{d} \mathrm{A}\end{array}$ & $\begin{array}{c}12.71 \pm 1.46 \\
(11.50) \text { ab }\end{array}$ \\
\hline $\mathrm{T}_{8}$ & $\begin{array}{l}0.83 \pm 0.07 \\
(8.16) \text { de } B\end{array}$ & $\begin{array}{l}0.91 \pm 0.03 \\
(3.71) \text { de } B\end{array}$ & $\begin{array}{l}0.91 \pm 0.12 \\
(12.80) \text { e B }\end{array}$ & $\begin{array}{l}1.16 \pm 0.07 \\
(5.79) \text { de } A\end{array}$ & $\begin{array}{c}1.29 \pm 0.07 \\
(5.42) \text { e A }\end{array}$ & $\begin{array}{c}15.14 \pm 4.51 \\
(29.79) a b\end{array}$ \\
\hline $\mathrm{T}_{9}$ & $\begin{array}{c}0.62 \pm 0.03 \\
(5.44) \text { e B } \\
\end{array}$ & $\begin{array}{l}0.69 \pm 0.07 \\
(10.20) \text { e B }\end{array}$ & $\begin{array}{l}1.00 \pm 0.15 \\
(15.23) \text { e A }\end{array}$ & $\begin{array}{c}1.01 \pm 0.07 \\
(6.62) \text { e A } \\
\end{array}$ & $\begin{array}{c}0.69 \pm 0.04 \\
(5.66) f B \\
\end{array}$ & $\begin{array}{c}19.96 \pm 7.47 \\
(37.42) \mathrm{b}\end{array}$ \\
\hline
\end{tabular}

$T_{1}-$ Soil $+0 \%$ of additions ( $0 \%$ residue $+100 \%$ cement) - control $; T_{2}-$ Soil $+10 \%$ of additions ( $10 \%$ rice husk $+90 \%$ cement); $T_{3}-$ Soil $+10 \%$ of additions ( $20 \%$ rice husk $+80 \%$ cement); $\mathrm{T}_{4}-$ Soil $+10 \%$ of additions ( $30 \%$ rice husk $+70 \%$ cement) $; \mathrm{T}_{5}-$ Soil $+10 \%$ of additions $\left(40 \%\right.$ rice husk $+60 \%$ cement); $\mathrm{T}_{6}-$ Soil $+10 \%$ of additions (10\% Brachiaria seed husk $+90 \%$ cement) $; T_{7}-$ Soil $+10 \%$ of additions ( $20 \%$ Brachiaria seed husk $+80 \%$ cement); $T_{8}-$ Soil $+10 \%$ of additions ( $30 \%$ Brachiaria seed husk $+70 \%$ cement) and; $T_{9}-$ Soil + $10 \%$ of additions ( $40 \%$ Brachiaria seed husk $+60 \%$ cement)

${ }^{1}$ Mean values + standard deviation (coefficient of variation, in \%); Means followed by the same lowercase letter in the columns do not differ by Tukey test ( $p<0.01$ ); Means followed by the same uppercase letter in the rows do not differ by Tukey test $(p<0.01)$ 
The ultrasonic wave propagation velocity increased with the age (Table 3) because of the gradual increment in the compounds resulting from cement hydration with the age, leading to crystalline structure of better quality and higher compacity and, consequently, favoring higher ultrasonic wave velocity (Brozovsky, 2014).

As a rule, the increase of age favored the decrease of total anisotropy (Table 3) through the reduction in the differences between the velocities in the three directions of the bricks, i.e., the gradual chemical stabilization by the cement, along the ages, favored the occurrence of lower differences between velocities, interpreted by the greater homogeneity of the physical-mechanical and elastic-acoustic behaviors evaluated in the three directions of the bricks.

There was a trend of increase in $\mathrm{R}_{\mathrm{A}}$ with the increment of age (Table 4). As already mentioned (Cultrone et al., 2001),

Table 3. Ultrasonic wave velocity in the three directions and total anisotropy of the bricks

\begin{tabular}{|c|c|c|c|c|c|c|c|c|c|c|}
\hline Age & Velocity $\left(\mathrm{m} \mathrm{s}^{-1}\right)$ & $\mathrm{T}_{1}$ & $\mathrm{~T}_{2}$ & $\mathrm{~T}_{3}$ & $\mathrm{~T}_{4}$ & $\mathbf{T}_{5}$ & $\mathrm{~T}_{6}$ & $\mathrm{~T}_{7}$ & $\mathbf{T}_{8}$ & $T_{9}$ \\
\hline \multirow{3}{*}{7 days } & $V_{1}$ & 1766 & 813 & 395 & 296 & 260 & 803 & 460 & 296 & 120 \\
\hline & $V_{2}$ & 1650 & 1206 & 883 & 653 & 576 & 1170 & 746 & 550 & 260 \\
\hline & $V_{3}$ & 1696 & 1313 & 973 & 460 & 340 & 1176 & 666 & 265 & 200 \\
\hline \multirow{3}{*}{28 days } & $V_{1}$ & 1340 & 830 & 701 & 336 & 225 & 795 & 445 & 210 & 161 \\
\hline & $V_{2}$ & 1466 & 1133 & 986 & 730 & 575 & 1200 & 653 & 330 & 210 \\
\hline & $V_{3}$ & 1496 & 1173 & 1106 & 823 & 516 & 1246 & 666 & 355 & 276 \\
\hline \multirow{3}{*}{56 days } & $V_{1}$ & 1531 & 1238 & 951 & 688 & 511 & 983 & 730 & 420 & 236 \\
\hline & $V_{2}$ & 1743 & 1533 & 1240 & 946 & 726 & 1340 & 1030 & 680 & 443 \\
\hline & $V_{3}$ & 1783 & 1576 & 1303 & 1103 & 673 & 1410 & 1110 & 743 & 576 \\
\hline \multirow{3}{*}{91 days } & $V_{1}$ & 1536 & 1160 & 793 & 576 & 430 & 1016 & 630 & 506 & 311 \\
\hline & $V_{2}$ & 1633 & 1320 & 1030 & 816 & 676 & 1196 & 786 & 710 & 376 \\
\hline & $V_{3}$ & 1730 & 1430 & 1116 & 830 & 723 & 1410 & 830 & 703 & 443 \\
\hline \multirow{3}{*}{182 days } & $V_{1}$ & 1650 & 883 & 1206 & 653 & 576 & 1170 & 746 & 550 & 260 \\
\hline & $V_{2}$ & 1830 & 1186 & 1400 & 886 & 740 & 1353 & 990 & 693 & 525 \\
\hline & $V_{3}$ & 1880 & 1536 & 1283 & 963 & 716 & 1483 & 1186 & 846 & 556 \\
\hline \multirow{2}{*}{ Treatment } & \multicolumn{10}{|c|}{ Total anisotropy (\%) - days } \\
\hline & \multicolumn{2}{|l|}{7} & \multicolumn{2}{|l|}{28} & \multicolumn{2}{|c|}{56} & \multicolumn{2}{|c|}{91} & \multicolumn{2}{|c|}{182} \\
\hline $\mathrm{T}_{1}{ }^{1}$ & \multicolumn{2}{|l|}{11.93} & \multicolumn{2}{|l|}{9.57} & \multicolumn{2}{|c|}{13.15} & \multicolumn{2}{|c|}{8.61} & \multicolumn{2}{|c|}{14.46} \\
\hline $\mathrm{T}_{2}$ & \multicolumn{2}{|l|}{35.41} & \multicolumn{2}{|l|}{28.09} & \multicolumn{2}{|c|}{20.37} & \multicolumn{2}{|c|}{15.38} & \multicolumn{2}{|c|}{22.36} \\
\hline $\mathrm{T}_{3}$ & \multicolumn{2}{|l|}{57.55} & \multicolumn{2}{|l|}{32.92} & \multicolumn{2}{|c|}{25.18} & \multicolumn{2}{|c|}{26.08} & \multicolumn{2}{|c|}{19.27} \\
\hline $\mathrm{T}_{4}$ & \multicolumn{2}{|l|}{46.63} & \multicolumn{2}{|l|}{56.44} & \multicolumn{2}{|c|}{32.82} & & & & \\
\hline $\mathrm{T}_{5}$ & 43.28 & & 58.83 & & & & & & & \\
\hline $\mathrm{T}_{6}$ & 31.49 & & 34.93 & & & & & & & \\
\hline $\mathrm{T}_{7}$ & 34.79 & & 37.01 & & & & & & & \\
\hline $\mathrm{T}_{8}$ & 27.35 & & 38.10 & & & & & & & \\
\hline $\mathrm{T}_{9}$ & 47.83 & & 33.48 & & & & & & & \\
\hline
\end{tabular}

$T_{1}-$ Soil $+0 \%$ of additions ( $0 \%$ residue $+100 \%$ cement) - control; $T_{2}-$ Soil $+10 \%$ of additions ( $10 \%$ rice husk $+90 \%$ cement) $;$ - Soil $+10 \%$ of additions ( $20 \%$ rice husk $+80 \%$ cement); $\mathrm{T}_{4}-$ Soil $+10 \%$ of additions ( $30 \%$ rice husk $+70 \%$ cement) $; \mathrm{T}_{5}-$ Soil $+10 \%$ of additions ( $40 \%$ rice husk $+60 \%$ cement); $\mathrm{T}_{6}-\mathrm{Soil}+10 \%$ of additions (10\% Brachiaria seed husk $+90 \%$ cement) $; \mathrm{T}_{7}-$ Soil $+10 \%$ of additions ( $20 \%$ Brachiaria seed husk $+80 \%$ cement); $\mathrm{T}_{8}-\mathrm{Soil}+10 \%$ of additions $\left(30 \%\right.$ Brachiaria seed husk $+70 \%$ cement) and; $\mathrm{T}_{9}-$ Soil + $10 \%$ of additions ( $40 \%$ Brachiaria seed husk $+60 \%$ cement)

Table 4. Anisotropic resistance of the bricks $\left(R_{A}\right)$

\begin{tabular}{|c|c|c|c|c|c|}
\hline \multirow{2}{*}{ Treatment } & \multicolumn{5}{|c|}{ Anisotropic resistance $\left(\mathrm{MPa} \%^{-1}\right)$ - days } \\
\hline & 7 & 28 & 56 & 91 & 182 \\
\hline $\mathrm{T}_{1}{ }^{1}$ & $\begin{array}{l}0.27 \pm 0.05 \\
(20.82) a C^{1}\end{array}$ & $\begin{array}{l}0.35 \pm 0.09 \\
(24.85) \text { a B }\end{array}$ & $\begin{array}{l}0.37 \pm 0.06 \\
(16.19) \text { a B }\end{array}$ & $\begin{array}{l}0.49 \pm 0.14 \\
(29.30) \text { a } A\end{array}$ & $\begin{array}{c}0.34 \pm 0.03 \\
(7.38) \mathrm{a} \mathrm{B}\end{array}$ \\
\hline $\mathrm{T}_{2}$ & $\begin{array}{c}0.05 \pm 0.00 \\
(5.76) \text { b B }\end{array}$ & $\begin{array}{c}0.08 \pm 0.01 \\
(13.13) \text { b AB }\end{array}$ & $\begin{array}{c}0.14 \pm 0.01 \\
(4.94) \text { b A }\end{array}$ & $\begin{array}{l}0.14 \pm 0.04 \\
(21.42) \mathrm{b} \mathrm{A}\end{array}$ & $\begin{array}{l}0.12 \pm 0.01 \\
(9.80) \text { b } A B\end{array}$ \\
\hline $\mathrm{T}_{3}$ & $\begin{array}{c}0.02 \pm 0.00 \\
(7.85) \text { b B }\end{array}$ & $\begin{array}{l}0.05 \pm 0.00 \\
(8.79) \text { b } A B\end{array}$ & $\begin{array}{l}0.09 \pm 0.01 \\
(6.69) \text { bc } A B\end{array}$ & $\begin{array}{c}0.07 \pm 0.00 \\
(7.26) \text { bc } A B\end{array}$ & $\begin{array}{r}0.12 \pm 0.01 \\
(5.63) \text { b A }\end{array}$ \\
\hline $\mathrm{T}_{4}$ & $\begin{array}{c}0.02 \pm 0.00 \\
(9.82) \text { b A }\end{array}$ & $\begin{array}{c}0.02 \pm 0.00 \\
(6.86) \text { b A }\end{array}$ & $\begin{array}{l}0.04 \pm 0.01 \\
(12.44) \text { C A }\end{array}$ & $\begin{array}{c}0.05 \pm 0.00 \\
(7.83) \subset A\end{array}$ & $\begin{array}{r}0.05 \pm 0.00 \\
(9.45) \subset A\end{array}$ \\
\hline $\mathrm{T}_{5}$ & $\begin{array}{c}0.02 \pm 0.00 \\
(1.30) \text { b A }\end{array}$ & $\begin{array}{c}0.02 \pm 0.00 \\
(4.90) \text { b A }\end{array}$ & $\begin{array}{c}0.04 \pm 0.00 \\
(8.20) \subset A\end{array}$ & $\begin{array}{c}0.03 \pm 0.00 \\
(3.26) \subset A\end{array}$ & $\begin{array}{l}0.05 \pm 0.01 \\
(14.38) \subset A\end{array}$ \\
\hline $\mathrm{T}_{6}$ & $\begin{array}{c}0.05 \pm 0.00 \\
(8.35) \text { b B }\end{array}$ & $\begin{array}{c}0.06 \pm 0.00 \\
(7.13) \text { b B }\end{array}$ & $\begin{array}{c}0.09 \pm 0.02 \\
(17.60) b c A B\end{array}$ & $\begin{array}{c}0.11 \pm 0.01 \\
(7.77) \text { bc } A B\end{array}$ & $\begin{array}{r}0.14 \pm 0.00 \\
(2.65) \mathrm{b} \mathrm{A}\end{array}$ \\
\hline $\mathrm{T}_{7}$ & $\begin{array}{c}0.03 \pm 0.00 \\
(5.77) \text { b A }\end{array}$ & $\begin{array}{l}0.03 \pm 0.00 \\
(14.77) \text { b A }\end{array}$ & $\begin{array}{c}0.05 \pm 0.00 \\
(7.24) \text { c A }\end{array}$ & $\begin{array}{l}0.08 \pm 0.02 \\
(19.51) \text { bc } A\end{array}$ & $\begin{array}{l}0.06 \pm 0.01 \\
(17.36) \subset A\end{array}$ \\
\hline $\mathrm{T}_{8}$ & $\begin{array}{l}0.03 \pm 0.01 \\
(32.26) b \mathrm{~A}\end{array}$ & $\begin{array}{l}0.02 \pm 0.00 \\
(17.04) b \mathrm{~b}\end{array}$ & $\begin{array}{l}0.02 \pm 0.00 \\
(14.93) \subset A\end{array}$ & $\begin{array}{c}0.04 \pm 0.00 \\
(6.11) \text { C A }\end{array}$ & $\begin{array}{c}0.05 \pm 0.01 \\
(9.36) \subset A\end{array}$ \\
\hline $\mathrm{T}_{9}$ & $\begin{array}{c}0.01 \pm 0.00 \\
(5.44) \text { b A }\end{array}$ & $\begin{array}{c}0.02 \pm 0.00 \\
(4.88) \text { b A }\end{array}$ & $\begin{array}{l}0.02 \pm 0.00 \\
(17.58) \subset A\end{array}$ & $\begin{array}{c}0.07 \pm 0.02 \\
(29.52) \text { bc } A\end{array}$ & $\begin{array}{l}0.01 \pm 0.00 \\
(24.44) \text { C A }\end{array}$ \\
\hline
\end{tabular}

$T-$ Soil $+0 \%$ of additions ( $0 \%$ residue $+100 \%$ cement) - control; $T$ - Soil $+10 \%$ of additions ( $10 \%$ rice husk $+90 \%$ cement); - Soil $+10 \%$ of additions ( $20 \%$ rice husk $+80 \%$ cement); $T_{4}-$ Soil $+10 \%$ of additions ( $30 \%$ rice husk $+70 \%$ cement) $; T_{5}-$ Soil $+10 \%$ of additions $\left(40 \%\right.$ rice husk $+60 \%$ cement); $T_{6}-$ Soil $+10 \%$ of additions ( $10 \%$ Brachiaria seed husk $+90 \%$ cement) $; T_{7}-$ Soil $+10 \%$ of additions ( $20 \%$ Brachiaria seed husk $+80 \%$ cement); $T_{8}-$ Soil $+10 \%$ of additions ( $30 \%$ Brachiaria seed husk $+70 \%$ cement) and; $T_{9}-$ Soil + $10 \%$ of additions ( $40 \%$ Brachiaria seed husk $+60 \%$ cement)

${ }^{1}$ Mean values + standard deviation (coefficient of variation, in \%); Means followed by the same lowercase letter in the columns do not differ by Tukey test ( $p<0.01$ ); Means followed by the same uppercase letter in the rows do not differ by Tukey test $(p<0.01)$ 
Table 5. Mean values of the dynamic modulus of elasticity of the bricks (Ed)

\begin{tabular}{|c|c|c|c|c|c|}
\hline \multirow{2}{*}{ Treat. } & \multicolumn{5}{|c|}{ Ed (MPa) - days } \\
\hline & 7 & 28 & 56 & 91 & 182 \\
\hline $\mathrm{T}_{1}$ & $\begin{array}{c}3497.97 \pm 205.80 \\
(5.88) \mathrm{a} \mathrm{C}^{1}\end{array}$ & $\begin{array}{c}2303.70 \pm 263.21 \\
(11.43) \text { a D }\end{array}$ & $\begin{array}{c}4524.03 \pm 647.24 \\
(14.31) \text { a B }\end{array}$ & $\begin{array}{c}3694.23 \pm 561.10 \\
(15.19) \text { a C }\end{array}$ & $\begin{array}{c}4956.32 \pm 90.68 \\
(1.83) \text { a A }\end{array}$ \\
\hline $\mathrm{T}_{2}$ & $\begin{array}{c}1059.37 \pm 20.18 \\
(1.90) b C\end{array}$ & $\begin{array}{c}633.20 \pm 6.21 \\
(0.98) \text { b D }\end{array}$ & $\begin{array}{c}2045.20 \pm 62.67 \\
(3.06) \text { b A }\end{array}$ & $\begin{array}{c}1675.93 \pm 124.89 \\
(7.45) \text { b B }\end{array}$ & $\begin{array}{c}1373.56 \pm 41.76 \\
(3.04) \text { b BC }\end{array}$ \\
\hline $\mathrm{T}_{3}$ & $\begin{array}{c}395.20 \pm 60.71 \\
(15.36) \text { c B }\end{array}$ & $\begin{array}{c}311.93 \pm 37.19 \\
(11.92) \text { c B }\end{array}$ & $\begin{array}{c}961.83 \pm 21.75 \\
(2.26) \text { c A }\end{array}$ & $\begin{array}{c}734.60 \pm 81.19 \\
(11.05) \mathrm{d} A B\end{array}$ & $\begin{array}{c}761.44 \pm 62.31 \\
(8.18) \mathrm{c} \mathrm{AB}\end{array}$ \\
\hline $\mathrm{T}_{4}$ & $\begin{array}{c}244.67 \pm 5.18 \\
(2.12) \mathrm{C} \mathrm{A}\end{array}$ & $\begin{array}{c}215.07 \pm 12.91 \\
(6.00) \text { C A }\end{array}$ & $\begin{array}{c}321.53 \pm 41.89 \\
(13.03) \mathrm{d} A\end{array}$ & $\begin{array}{c}369.37 \pm 42.21 \\
(11.43) \text { de A }\end{array}$ & $\begin{array}{c}246.56 \pm 6.09 \\
(2.47) \mathrm{d} \mathrm{A}\end{array}$ \\
\hline $\mathrm{T}_{5}$ & $\begin{array}{c}325.57 \pm 4.16 \\
(1.28) \text { c } A\end{array}$ & $\begin{array}{c}222.20 \pm 0.00 \\
(0.00) \text { c A }\end{array}$ & $\begin{array}{c}214.60 \pm 12.18 \\
(5.68) \mathrm{d} \mathrm{A}\end{array}$ & $\begin{array}{c}264.57 \pm 21.43 \\
(8.10) \text { e A }\end{array}$ & $\begin{array}{c}223.26 \pm 10.95 \\
(4.90) \mathrm{d} \mathrm{A}\end{array}$ \\
\hline $\mathrm{T}_{6}$ & $\begin{array}{c}1308.40 \pm 91.57 \\
(7.00) \text { b A }\end{array}$ & $\begin{array}{c}911.63 \pm 36.11 \\
(3.96) \text { b B }\end{array}$ & $\begin{array}{c}1148.20 \pm 12.70 \\
(1.11) \subset A B\end{array}$ & $\begin{array}{c}1185.50 \pm 4.60 \\
(0.39) \mathrm{c} A B\end{array}$ & $\begin{array}{c}1463.84 \pm 28.50 \\
(1.95) \text { b A }\end{array}$ \\
\hline $\mathrm{T}_{7}$ & $\begin{array}{c}542.30 \pm 26.83 \\
(4.95) \text { c A }\end{array}$ & $\begin{array}{c}301.40 \pm 11.76 \\
(3.90) \text { c A }\end{array}$ & $\begin{array}{c}521.20 \pm 17.57 \\
(13.37) \mathrm{d} \mathrm{A}\end{array}$ & $\begin{array}{c}425.53 \pm 42.95 \\
(10.09) \text { de A }\end{array}$ & $\begin{array}{c}586.19 \pm 0.56 \\
(0.10) \subset A\end{array}$ \\
\hline $\mathrm{T}_{8}$ & $\begin{array}{c}351.87 \pm 20.05 \\
(5.70) \text { C A }\end{array}$ & $\begin{array}{c}203.37 \pm 4.74 \\
(2.33) \text { c A }\end{array}$ & $\begin{array}{c}251.40 \pm 12.92 \\
(5.14) \mathrm{d} A\end{array}$ & $\begin{array}{c}287.00 \pm 45.26 \\
(15.77) \text { e } A\end{array}$ & $\begin{array}{c}218.45 \pm 1.27 \\
(0.58) \mathrm{d} A\end{array}$ \\
\hline $\mathrm{T}_{9}$ & $\begin{array}{c}273.67 \pm 2.98 \\
(1.09) \text { c A }\end{array}$ & $\begin{array}{c}159.37 \pm 0.53 \\
(0.53) \text { c A }\end{array}$ & $\begin{array}{c}244.70 \pm 53.25 \\
(21.76) \mathrm{d} \mathrm{A}\end{array}$ & $\begin{array}{c}197.83 \pm 29.82 \\
(15.12) \text { e A }\end{array}$ & $\begin{array}{c}99.11 \pm 3.98 \\
(4.02) \mathrm{d} \mathrm{A}\end{array}$ \\
\hline
\end{tabular}

$\mathrm{T}_{1}-$ Soil $+0 \%$ of additions ( $0 \%$ residue $+100 \%$ cement) - control; $\mathrm{T}_{2}-$ Soil $+10 \%$ of additions (10\% rice husk $+90 \%$ cement); $\mathrm{T}_{3}-$ Soil $+10 \%$ of additions ( $20 \%$ rice husk $+80 \%$ cement); $T_{-}-$Soil $+10 \%$ of additions (30\% rice husk $+70 \%$ cement); $T_{5}-$ Soil $+10 \%$ of additions ( $40 \%$ rice husk $+60 \%$ cement); $T_{6}-$ Soil $+10 \%$ of additions (10\% Brachiaria seed husk $+90 \%$ cement); $T_{7}-$ Soil $+10 \%$ of additions ( $20 \%$ Brachiaria seed husk $+80 \%$ cement); $T_{8}-$ Soil $+10 \%$ of additions ( $30 \%$ Brachiaria seed husk $+70 \%$ cement) and; $T_{9}-$ Soil + $10 \%$ of additions ( $40 \%$ Brachiaria seed husk $+60 \%$ cement)

${ }^{1}$ Mean values + standard deviation (coefficient of variation, in \%); Means followed by the same lowercase letter in the columns do not differ by Tukey test ( $p<0.01$ ); Means followed by the same uppercase letter in the rows do not differ by Tukey test $(p<0.01)$

high $\mathrm{R}_{\mathrm{A}}$ indicates low anisotropy associated with the lower presence of voids, higher mechanical resistance and durability.

The residue contents that allowed to achieve highest and lowest $\mathrm{R}_{\mathrm{A}}$ were those corresponding to $10 \%$ rice husk $\left(\mathrm{T}_{2}\right)$ and $40 \%$ Brachiaria seed husk $\left(\mathrm{T}_{9}\right)$, respectively. As the resistance to compression, the $\mathrm{R}_{\mathrm{A}}$ of the treatments with rice husk was higher than that relative to Brachiaria seed husk.

The values of dynamic modulus of elasticity (Ed) tended to increase with the ages of the bricks (Table 5). Since the Ed strongly depends on the ultrasonic wave propagation velocity, because it varies with its square, Ed values followed the trend of increase of velocity over the storage time (Table 5). The highest Ed values were 4524 and $2045 \mathrm{MPa}$, for the treatments $\mathrm{T}_{1}$ and $\mathrm{T}_{2}$, respectively, which were much higher than those reported for the traditional adobes, which vary from 100 to $300 \mathrm{MPa}$ (Piattoni et al., 2011; Adorni et al., 2013).

The obtained results confirm the positive effect of the processes of mechanical stabilization (pressing) and chemical stabilization (use of cement) on the quality of the bricks manufactured with incorporation of the studied residues, constituting an alternative that is adequate to the traditional adobes (manual molding) and to the ceramic fire bricks in technical and ecological terms, respectively, under equal conditions of use.

Likewise, the combination of the effects of the mechanical stress (destructive tests) and anisotropic structure of the bricks indicates the "anisotropic resistance" as a viable qualitative parameter to evaluate the quality of bricks made of mechanically and chemically stabilized raw earth.

\section{Conclusions}

1. Additions of rice husk resulted in higher values of resistance to simple compression, at all contents and ages, compared with those obtained with Brachiaria seed husk.
2. There were differences in the ultrasonic wave velocities measured in the three directions of the bricks, represented by the presence of structural anisotropy of these materials.

3. There was a reduction in the apparent specific weight of the bricks with the additions of plant residues, thus resulting in lower values of anisotropic resistance.

4. The values of anisotropic resistance of the treatments with rice husk were higher than those relative to Brachiaria seed husk.

5. The residue contents that led to best and worst technical quality, evaluated through the anisotropic resistance were, respectively, $10 \%$ rice husk $\left(\mathrm{T}_{2}\right)$ and $40 \%$ Brachiaria seed husk $\left(\mathrm{T}_{9}\right)$.

\section{Literature Cited}

ABNT - Associação Brasileira de Normas Técnicas. NBR 10832. Fabricação de tijolo maciço de solo-cimento com a utilização de prensa manual. Rio de Janeiro: ABNT, 1989.3p.

ABNT - Associação Brasileira de Normas Técnicas. NBR 11578. Cimento Portland CPII-E32. Rio de Janeiro: ABNT, 1991. 5p.

ABNT - Associação Brasileira de Normas Técnicas. NBR 08491. Tijolo maciço de solo-cimento. Rio de Janeiro: ABNT, 1992a. 8p. ABNT - Associação Brasileira de Normas Técnicas. NBR 08492. Tijolo maciço de solo-cimento. Determinação da resistência à compressão e absorção de água. Rio de Janeiro: ABNT, 1992b. 8p. Adorni, E.; Coïsson, E.; Ferretti, D. In situ characterization of archaeological adobe bricks. Construction and Building Materials, v.40, p.1-9, 2013. https://doi.org/10.1016/j.conbuildmat.2012.11.004

Brozovsky, J. Determine the compressive strength of calcium silicate bricks by combined nondestructive method. The Scientific World Journal, v.2014, p.1-5, 2014. https://doi.org/10.1155/2014/829794

Carrasco, E. V. M.; Silva, S. R.; Mantilla, J. N. R. Assessment of mechanical properties and the influence of the addition of sawdust in soil-cement bricks using the technique of ultrasonic anisotropic inspection. Journal of Materials in Civil Engineering, v.26, p.219225, 2014. https://doi.org/10.1061/(ASCE)MT.1943-5533.0000723 
Cazalla, O.; Sebastián, E.; Cultrone, G.; Nechar, M.; Bagur, M. G. Three-way ANOVA interaction analysis and ultrasonic testing to evaluate air lime mortars used in cultural heritage conservation projects. Cement and Concrete Research, v.29, p.1749-1752, 1999. https://doi.org/10.1016/S0008-8846(99)00158-1

Cruz, M. de L.: Jalali, S. Improvement of soils stabilized with cement performance using low cost activators. Revista Luso-Brasileira de Geotecnia, v.120, p.49-64, 2010.

Cultrone, G.; Sebastián, E.; Cazalla, O.; Nechar, M.; Romero, R.; Bagur, M. G. Ultrasound and mechanical tests combined with ANOVA to evaluate brick quality. Ceramics International, v.27, p.401-406, 2001. https://doi.org/10.1016/S0272-8842(00)00094-8

Faria, K. C. P.; Gurgel, R. F.; Holanda, J. N. F. Recycling of sugarcane bagasse ash waste in the production of clay bricks. Journal of Environmental Management, v.101, p.7-12, 2012. https://doi. org/10.1016/j.jenvman.2012.01.032

Ferreira, R. de C.; Freire, W. J. Eficiência da estabilização do solo e qualidade de tijolos prensados de terra crua tratada com aditivos químicos, avaliadas pela combinação de testes destrutivos e nãodestrutivos. Engenharia Agrícola, v.24, p.1-15, 2004. https://doi. org/10.1590/S0100-69162004000300003

Ferreira, R. de C.; Gobo, J. C. da C.; Cunha, A. H. N. Incorporação de casca de arroz e de braquiária e seus efeitos nas propriedades físicas e mecânicas de tijolos de solo-cimento. Engenharia Agrícola, v.28, p.1-11, 2008. https://doi.org/10.1590/S0100-69162008000100001

Ferreira, R. de C.; Oliveira, M. F. Incorporação de resíduos vegetais e seus efeitos sobre as características físico-mecânicas de misturas de solo-cimento para fins de construção rural. Pesquisa Agropecuária Tropical, v.37, p.204-213, 2007.

Ganga, G.; Nsongo, T.; Elenga, H.; Mabiala, B.; Tatsiete, T. T. Effect of incorporation of chips and wood dust mahogany on mechanical and acoustic behavior of brick clay. Journal of Building Construction and Planning Research, v.2, p.198-208, 2014. https:// doi.org/10.4236/jbcpr.2014.23018

Jauberthie, R.; Rendell, F.; Tamba, S.; Cissé, I. K. Properties of cementrice husk mixture. Construction and Building Materials, v.17, p.239-243, 2003. https://doi.org/10.1016/S0950-0618(03)00005-9
Khedari, J.; Watsanasathaporn, P.; Hirunlabh, J. Development of fibrebased soil-cement block with low thermal conductivity. Cement and Concrete Composites, v.27, p.111-116, 2005. https://doi. org/10.1016/j.cemconcomp.2004.02.042

Laborel-Préneron, A.; Aubert, J. E.; Magniont, C.; Tribout, C.; Bertron, A. Plant aggregates and fibers in earth construction materials: A review. Construction and Building Materials, v.111, p.719-734, 2016. https://doi.org/10.1016/j.conbuildmat.2016.02.119

Madurwar, M. V.; Ralegaonkar, R. V.; Mandavgane, S. A. Application of agro-waste for sustainable construction materials: A review. Construction and Building Materials, v.38, p.872-878, 2013. https://doi.org/10.1016/j.conbuildmat.2012.09.011

Milani, A. P. da S.; Freire, W. J. Características físicas e mecânicas de misturas de solo, cimento e casca de arroz. Engenharia Agrícola, v.26, p.1-10, 2006. https://doi.org/10.1590/S0100-69162006000100001

Mosalam, K.; Glascoe, L.; Bernier J. Mechanical properties of unreinforced brick masonry Section 1. Washington, DC: Department of Energy/ Lawrence Livermore National Laboratory, CA. 2009. 26p. https://doi.org/10.2172/966219

Naik, T. R.; Malhotra, V. M.; Popovics, J. S. The ultrasonic pulse velocity method. Boca Raton: CRC Press, 2014. 19p.

Piattoni, Q.; Quagliarini, E.; Lenci, S. Experimental analysis and modelling of the mechanical behaviour of earthen bricks. Construction and Building Materials, v.25, p.2067-2075, 2011. https://doi.org/10.1016/j.conbuildmat.2010.11.039

Qasrawi, H. Y. Concrete strength by combined nondestructive methods simply and reliably predicted. Cement and Concrete Research, v.30, p.739-746. 2000. https://doi.org/10.1016/S0008-8846(00)00226-X

Ramakrishna, G.; Sundararajan, T. Studies on the durability of natural fibres and the effect of corroded fibres on the strength of mortar. Cement and Concrete Composites, v.27, p.575-582, 2005. https:// doi.org/10.1016/j.cemconcomp.2004.09.008

Yu, Q.; Sawayama, K.; Sugita, S.; Shoya, M.; Isojima, Y. The reaction between rice husk ash and $\mathrm{Ca}(\mathrm{OH})_{2}$, solution and the nature of its product. Cement and Concrete Research, v.29, p.37-43, 1999. https://doi.org/10.1016/S0008-8846(98)00172-0

Zhang, L. Production of bricks from waste materials - A review. Construction and Building Materials, v.47, p.643-655, 2013. https://doi.org/10.1016/j.conbuildmat.2013.05.043 